\title{
Variation of Hydroxyapatite Content in Soft Gelatin Affects Mesenchymal Stem Cell Differentiation
}

\author{
Fahsai Kantawong1*, Junijira Tanum²; Wassanai Wattanutchariya ${ }^{3}$; Pat Sooksaen ${ }^{4}$ \\ ${ }^{1}$ Division of Clinical Chemistry - Department of Medical Technology, Faculty of Associated Medical Sciences, \\ Chiang Mai University, Chiang Mai, Thailand. ${ }^{2}$ Biomedical Engineering Center, Chiang Mai University, \\ Thailand. ${ }^{3}$ Department of Industrial Engineering, Faculty of Engineering, Chiang Mai University, Thailand. \\ ${ }^{4}$ Department of Materials Science and Engineering, Faculty of Advanced Materials Science and \\ Nanotechnology, Silpakorn University, Thailand.
}

\begin{abstract}
Gelatin is a common material used in tissue engineering and hydroxyapatite (HA) has a composition and structure similar to natural bone mineral. HA is also used to increase the adhesion ability of scaffolds. The physical and mechanical properties of gelatin, together with the chemical properties of HA, can affect cell differentiation. The main purpose of this study is to investigate the gene expression of human mesenchymal stem cells (HMSCs) upon culturing on gelatin composite with HA. Low amounts of HA were introduced into the gelatin in order to modulate properties of gelatin. Three types of hydrogel were fabricated by glutaraldehyde crosslinking before lyophilization to produce the porous $3 \mathrm{D}$ structure: (1) pure gelatin, (2) $0.5 \mathrm{mg} / \mathrm{ml} \mathrm{HA}$ in gelatin, and (3) $1 \mathrm{mg} / \mathrm{ml} \mathrm{HA}$ in gelatin. The fabricated hydrogels were used as scaffolds to cultivate HMSCs for two periods - 24 hours and 3 weeks. The results showed that all types of fabricated hydrogels could be used to cultivate HMSCs. Changes of gene expressions indicated that the HMSCs cultured on the $1 \mathrm{mg} / \mathrm{ml} \mathrm{HA}$ in gelatin showed neuronal lineage-specific differentiation.
\end{abstract}

Key words: Gelatin; Hydroxyapatite; Mesenchymal stem cells; Gene Expression

${ }^{1}$ Author for correspondence: fahsai.k@cmu.ac.th 


\section{INTRODUCTION}

The elasticity of soft hydrogel can be used as mechanical stimuli to regulate cell behaviors, such as cell morphology, proliferation, differentiation, adhesion, and migration (Kuboki et al., 2012; Kantawong et al., 2015). Cultivation of HMSCs on soft gelatin induced expression of early neuronal marker, beta-III tubulin gene (Kantawong et al., 2015). Moreover, adding calcium phosphate might improve the physical and chemical properties of gelatin, as a previous study found that HA increased cell adhesion, proliferation, and detachment strength (Deligianni et al., 2001). Previous study indicated that a nano-structured scaffold for bone repair using HA and gelatin was successfully developed for osteoblast-like cells (Azami et al., 2012). Furthermore, a nanostructured scaffold for bone repair using nanohydroxyapatite and gelatin as the main components showed osteogenicity for unrestricted somatic stem cells (Tavakol et al., 2013). Although HA is commonly used in biomaterials for bone differentiation, it has also been used to enhance neural differentiation. A previous study suggested that there is no harm in using calcium phosphate cement near the peripheral nerve fibers (Munemoto et al., 2010).

Undifferentiated adipose tissue-derived stem cells were cultured in a nerve guide conduit containing gelatin with tricalcium phosphate ceramic particles and were then used as a guidance channel for regenerating damaged sciatic nerves of rats (Shen et al., 2012; Liu et al., 2014). It was possible that the $\mathrm{Ca}^{2+}$ ions that were released into the medium stimulated the calcium sensing receptor and resulted in the early-stage neurogenic differentiation (Martino et al., 2014).

Our previous study used hydrogel fabricated by glutaraldehyde crosslinking and freezedrying to produce a porous $3 \mathrm{D}$ structure (Tanum et al., 2016). Three types of hydrogel were produced - (1) pure gelatin, (2) 0.5 $\mathrm{mg} / \mathrm{ml} \mathrm{HA}$ in gelatin, and (3) $1 \mathrm{mg} / \mathrm{ml} \mathrm{HA}$ in gelatin - and used to culture HMSCs; cells were successfully cultivated. Cell staining and microscopic observation revealed that the human HMSCs cultured on the fabricated hydrogels did not show any lineage-specific differentiation. The aim of this study is to investigate the change of gene expression using real time-PCR, which reflect changes in
HMSC behavior and differentiation. Cell adhesion was evaluated with the gene expression of actin, nestin, gelsolin, and paxillin, following a 24-hour incubation period. Furthermore, cell differentiation was determined with the expression of osteopontin $(\mathrm{OPN})$, osteocalcin $(\mathrm{OCN})$, beta-III tubulin (TUBB3), and microtubule-associated protein 2 (MAP2) gene, following a 3-week incubation period.

\section{MATERIAL AND METHODS}

\section{Preparation of hydrogel}

A $10 \%$ gelatin solution was prepared as described previously (Tanum et al., 2016). Briefly, gelatin powder was dissolved in sterile water at $50{ }^{\circ} \mathrm{C}$ for 45 minutes in a water bath. Then the solution was stirred for 30 minutes at $50{ }^{\circ} \mathrm{C}$ on a stirrer. After that, the gelatin solution and HA were mixed together for 30 minutes. To decrease the aggregation of HA, the solution was incubated in an ultrasonic bath for 45 minutes. Glutaraldehyde $2.5 \mu 1 / \mathrm{ml}$ was added to initiate gel crosslinking. Two $\mathrm{ml}$ of gelatin solution was set in 6-well plates and left at room temperature for $24 \mathrm{hrs}$. Gels were rinsed with sterile water 3 times, before soaking overnight in sterile water. Finally, gels were kept at

$-20{ }^{\circ} \mathrm{C}$ for $24 \mathrm{hrs}$, before freeze-drying for 12 hrs.

\section{Mesenchymal stem cell pre-culture}

Mesenchymal stem cells (Immortalized human MSCs; Health Sciences Research Resource Bank, Osaka, Japan) were seeded into $75 \mathrm{~cm}^{2}$ tissue culture flasks with $20 \mathrm{ml}$ of Dulbecco's modified Eagles medium (DMEM) with $10 \%$ fetal calf serum (FCS) and 1\% Pen/Strep. Non-adherent cells were removed and the culture medium was changed every 3 days, while the cultured condition was maintained at $37{ }^{\circ} \mathrm{C}$ under $5 \% \mathrm{CO}_{2}$ in the incubator. At $80 \%$ confluence, the MSCs were washed twice with 1xPBS. After that, cells were detached by $0.25 \%$ trypsin-EDTA for 3 minutes at $37{ }^{\circ} \mathrm{C}$ in an incubator and the cells were counted using a counting chamber.

\section{Mesenchymal stem cell culture}

The composite hydrogels (in 6-well plates) were sterilized in $70 \%$ ethyl alcohol for 5 minutes before soaking in DMEM for 15 minutes 3 times. Cells were added onto the 
hydrogel with a seeding density of $1 \times 10^{4}$ cells/well and the condition was maintained at $37{ }^{\circ} \mathrm{C}$ under $5 \% \mathrm{CO}_{2}$ in the incubator.

\section{Gene expression}

Cells were cultured for the desired periods. The culture medium was discarded and $1 \mathrm{x}$ PBS was added to wash the cells. Then, the total RNA extraction was performed using High Pure RNA Isolation Kit (Roche), according to the manufacturer's protocol. The amount of total RNA was quantified by NanoDrop 2000 spectrophotometer (Thermo Scientific). Then, genomic DNA was eliminated with the addition of DNase reaction mixture (Macherey-Nagel) into total RNA (1 $\mu \mathrm{l}$ DNAse/10 $\mu$ l RNA) and incubated at $37{ }^{\circ} \mathrm{C}$ for $10 \mathrm{~min}$. cDNA was synthesized using iScript Reverse Transcription Supermix and the reverse transcription reaction was performed in an Eppendorf Mastercycler ${ }^{\circledR}$. The cDNA was synthesized as the following program; 1) priming at $25^{\circ} \mathrm{C}$ for 5 minutes, 2) transcription at $42{ }^{\circ} \mathrm{C}$ for 30 minutes and 3) inactivation at $85{ }^{\circ} \mathrm{C}$ for 5 minutes. NO-RT reaction was prepared as a negative control. RT-PCR was performed using SYBR Green Mastermix (SensiFAST SYBR ${ }^{\circledR}$ No-ROX Kit-Bioline). Briefly, cDNA was diluted 1:10 and the $10-\mu \mathrm{l}$ reaction was composed of $5 \mu \mathrm{l}$ of SYBR Green RT-PCR master mix, $1 \mu \mathrm{L}$ of cDNA template, $3.5 \mu \mathrm{l}$ of distilled water, and $0.25 \mu \mathrm{M}$ of target-specific primer. RT-PCR was performed in LightCycler480 (Roche) and the polymerase chain reaction protocol consisted of $95{ }^{\circ} \mathrm{C}$ pre-incubation for 2 minutes, followed by 40 cycles of $95{ }^{\circ} \mathrm{C}$ for 5 seconds, $60{ }^{\circ} \mathrm{C}$ for 10 seconds, and $72{ }^{\circ} \mathrm{C}$ for 10 seconds. The melting peak analysis was performed at $95{ }^{\circ} \mathrm{C}$ for 5 seconds, $65^{\circ} \mathrm{C}$ for 1 minute, and $97{ }^{\circ} \mathrm{C}$ continuous. The cooling step was performed at $40{ }^{\circ} \mathrm{C}$ for 30 seconds. GAPDH was used as a reference gene. The relative quantification was performed using LightCycler® 480 software 1.5. The list of primers is shown in Table 1.

Table 1 List of primers: The table shows the primer's sequences of each gene.

\begin{tabular}{|c|c|}
\hline Target genes & Primer sequences (5'-3') \\
\hline Paxillin & F: AACAAGCAGAAGTCAGCAGAGCC \\
\hline$(\mathrm{PXN})$ & R: CTAGCTTGTTCAGGTCGGAC \\
\hline Gelsolin & F: CAGCCTCTGACTTCATCTCCAAG \\
\hline$(\mathrm{GSN})$ & R: CACGTTGGCAATGTGGCTGGAG \\
\hline \multirow[t]{2}{*}{$£$-actin } & F: AGAAAATCTGGCACCACACC \\
\hline & R: AGAGGCGTACAGGGATAGCA \\
\hline$\beta$-III-tubulin & F: CGCACGACATCTAGGACTGA \\
\hline (TUBB3) & R: TGAGGCCTCCTCTCACAAGT \\
\hline \multirow[t]{2}{*}{ Nestin } & F: GTCTCAGGACAGTGCTGAGCCTTC \\
\hline & R: TCCCCTGAGGACCAGGAGTCTC \\
\hline Osteocalcin & F: GCAAGTAGCGCCAATCTAGG \\
\hline$(\mathrm{OCN})$ & R: GCTTCACCCTCGAAATGGTA \\
\hline Osteopontin & F: GGACAGCCAGGACTCCATTG \\
\hline$(\mathrm{OPN})$ & R: TGTGGGGACAACTGGAGTGAA \\
\hline Microtubule-associated protein 2 & F: CCAAGGAGTCTGATTGCAGGA \\
\hline (MAP2) & R: CCTCAACCACAGCTCAAATGC \\
\hline Glyceraldehyde-3-phosphate dehydrogenase & F: AAGGGCTCATGACCACAGTC \\
\hline (GAPDH) & R: GGATGACCTTGCCCACAG \\
\hline
\end{tabular}

\section{Statistical analysis}

The gene expression level was presented as mean \pm 2 SD. Statistical analysis was conducted using SPSS. The results were considered significant at $P<0.05$. Student's $t$-test was used to determine the significance of study parameters between two groups. 


\section{RESULTS AND DISCUSSION}

\section{Preparation of hydrogel}

The dry scaffolds are shown in Fig.1. The macroscopic and microscopic appearances of the scaffolds are very similar to each other (Fig. $1 \&$ Fig. 2). This result correlated with a previous study by Tanum et al., which indicated that all types of the scaffold showed hetergeneous porosity with approximate size within 100-350 $\mu \mathrm{m}$ (Tanum et al., 2016). Moreover, the previous study demonstrated that pure gelatin hydrogel had the highest $\%$ swelling and \%swelling decreased when the HA content was increased (Tanum et al., 2015).

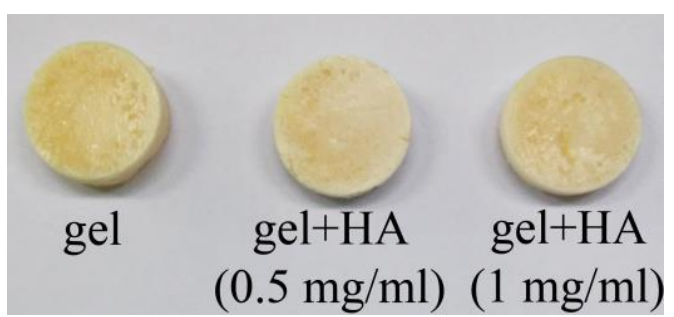

Figure 1 - Dry scaffold: Macroscopic appearances of the scaffolds are similar in all types.
Previous studies presented the feasibility and biocompatibility of HA-supplemented gels for culturing MSCs (Laydi et al., 2013; Tanum et al., 2015). This present study aimed to investigate the influence of HA content added into gelatin. The results showed that small variations in HA content affected gene expression since 24 hours of cell attachment. The results of gene expression after long-term culture indicated that small variations in HA content might drive different cell fates.

The expressions of normal cytoskeleton and focal adhesion protein - i.e., actin, nestin, gelsolin, and paxilin- were investigated at 24 hours. Specific groups of differentiation marker - i.e., OPN, OCN, TUBB3, and MAP2 - were investigated at 3 weeks.

\section{Gene expression at 24 hours}

ק-actin: The addition of $0.5 \mathrm{mg} / \mathrm{ml}$ of HA into hydrogel did not affect expression of $\square$-actin (Fig. 2). HMSCs cultured on gelatin containing $1 \mathrm{mg} / \mathrm{ml}$ HA showed decreased actin expression (Fig. 3). It is possible that 0.5 $\mathrm{mg} / \mathrm{ml}$ of HA had little effect on the physical property of hydrogel, so it did not affect the cytoskeletal arrangement at 24 hours.

\section{Gene expression}

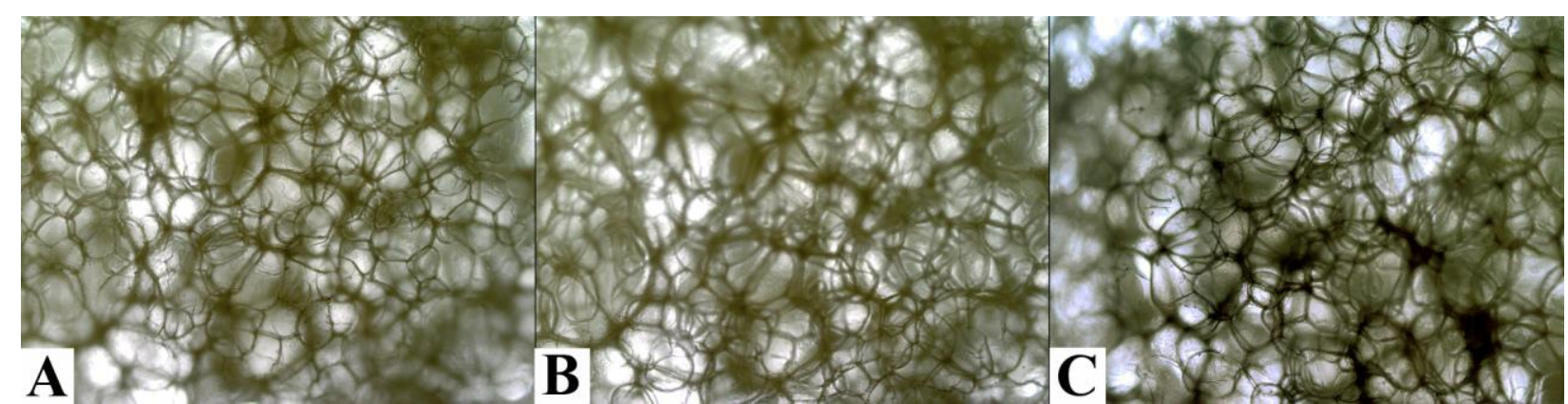

Figure 2 - Microscopic appearance: Dry scaffolds observed under light microscope show similar pattern of pore formation.

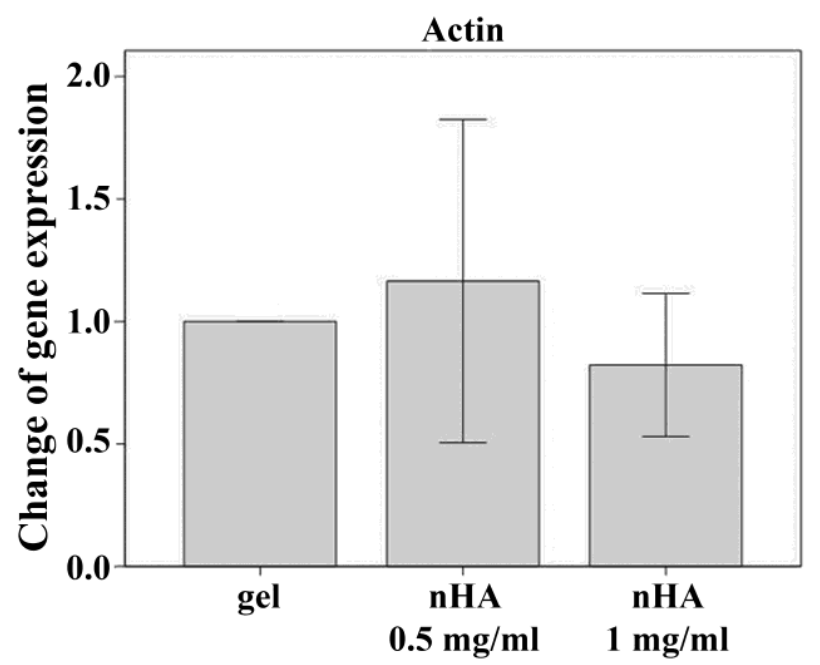


Figure 3 - Expression of $\beta$-actin gene: At 24 hours, the expression of $\beta$-actin gene decreased insignificantly on gelatin that contained $1 \mathrm{mg} / \mathrm{ml}$ of $\mathrm{HA}$.

However, $1 \mathrm{mg} / \mathrm{ml}$ of $\mathrm{HA}$ affected the gelatin properties. Banat and Tinçer reported that HA might interrupt cross-linking of polymer (Banat and Tinçer, 2003). The expression of $\beta$ -actin significantly decreased when HMSCs were cultured on gelatin composite $1 \mathrm{mg} / \mathrm{ml}$ HA. This phenomenon might reflect the physical properties of the scaffold. This result correlated with previous studies which demonstrated that filamentous (F)-actin decreased on a softer substrate (Yeung et al., 2005; Solon et al., 2007).

Nestin: At 24 hours, the expression of nestin gene increased significantly on gelatin composite HA (Fig. 4). It is known that soft substrates support the expression of nestin compared to stiff substrates (Engler et al., 2006). Thus, this result might imply that adding HA into gelatin makes a softer hydrogel. Moreover, up-regulation of nestin was sometimes used as a neuronal progenitor marker (Suzuki et al., 2010).

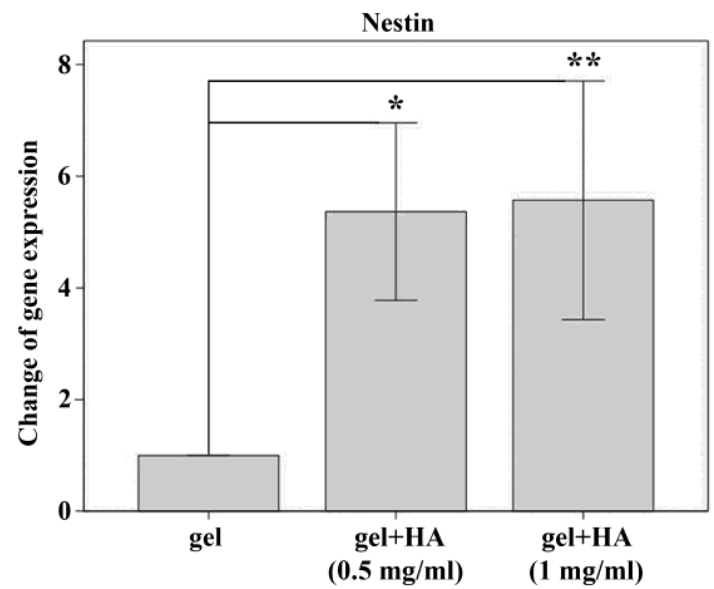

Figure 4 - Expression of nestin gene: At 24 hours, the expression of nestin gene increased significantly on gelatin composite HA.

Gelsolin and paxillin: At 24 hours, the expression of gelsolin and paxillin gene increased significantly on gelatin composite HA (Fig.5 \& Fig. 6). Gelsolin is a calciumactivated protein that acts as actin filament severing and capping protein (Gremm and Wegner, 2000). On soft substrates, F-actin exhibits load-and-fail dynamics (Chan and Odde, 2008). Previous studies suggested that gelsolin enhanced actin dynamics (Southwick, 2000) by severing F-actin in the high$\mathrm{Ca}^{2+}$ environment (Selden et al., 1998).

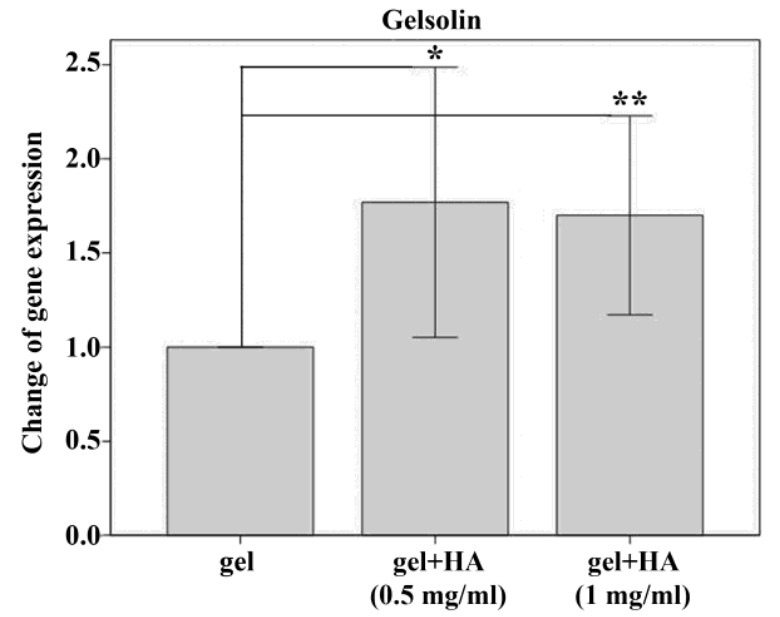

Figure 5 - Expression of gelsolin gene: At 24 hours, the expression of gelsolin gene increased significantly on gelatin composite HA.

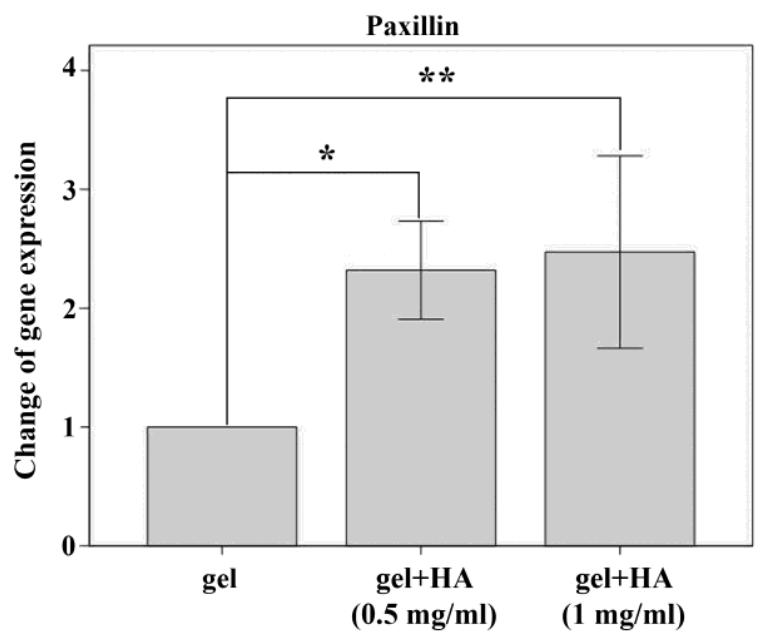

Figure 6 - Expression of paxillin gene: At 24 hours, the expression of paxillin gene increased significantly on gelatin composite HA.

Calcium can also induce up-regulation of cytoplasmic gelsolin (Ji et al., 2010). The HA particles provided anchorage sites, allowing for more focal adhesion formation (Miyamoto et al., 1995; Engler et al., 2004). HA improved surface properties, which affected cell attachment via formation of focal contacts (Deligianni et al., 2001). Paxillin localized at sites of cell adhesion to the surface, called focal adhesions (Turner et al., 1990; Turner, 2000). Increased expression of paxillin might be due to increased focal adhesion formation. Normally, focal adhesion of cells is less on a soft substrate (Discher et al., 2005; Walcott et al., 2011), but the addition of an optimal 
amount of HA into the gelatin might increase static focal adhesion on a soft substrate, and this phenomenon is enough to trigger some neuronal gene expression.

\section{Gene expression at 3 weeks}

Osteogenic markers: HMSCs expressed higher OCN when they were cultured on gelatin with $0.5 \mathrm{mg} / \mathrm{ml}$ of HA (Fig. 7). The expression of OPN was up-regulated on both gelatin with 0.5 and $1 \mathrm{mg} / \mathrm{ml}$ of HA (Fig. 8).

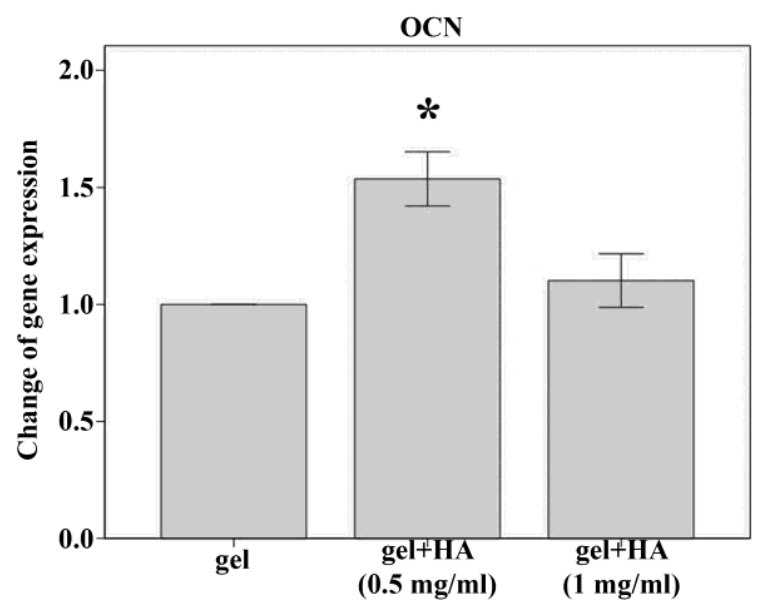

Figure 7 - Expression of OCN gene: At 3 weeks, the expression of OCN gene increased significantly on gelatin that contained $0.5 \mathrm{mg} / \mathrm{ml}$ of HA.

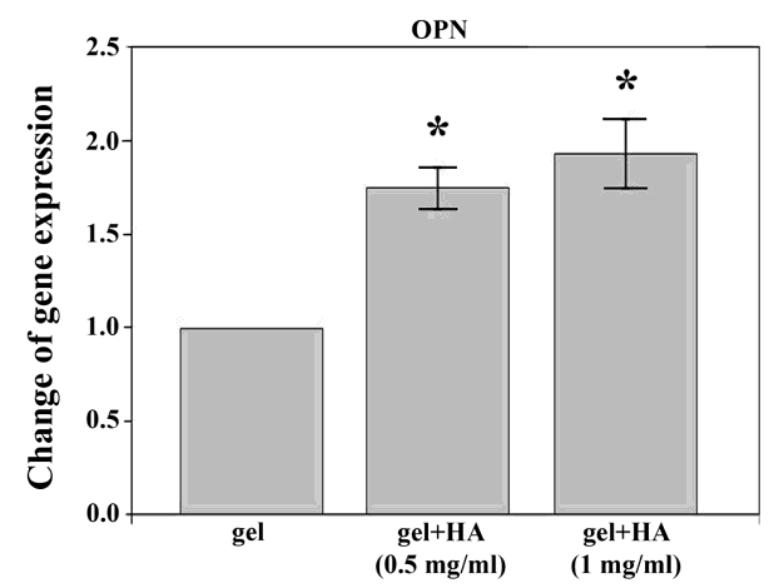

Figure 8 - Expression of OPN gene: At 3 weeks, the expression of OPN gene increased significantly on gelatin composite HA. The highest level of expression was found on gelatin that contained 1 $\mathrm{mg} / \mathrm{ml}$ of HA.

Neurogenic markers: The expression of TUBB3 and MAP2 significantly increased in MSCs cultured on gelatin with $1 \mathrm{mg} / \mathrm{ml}$ of HA (Fig. 9 \& Fig. 10). This result is related to the result of nestin expression.

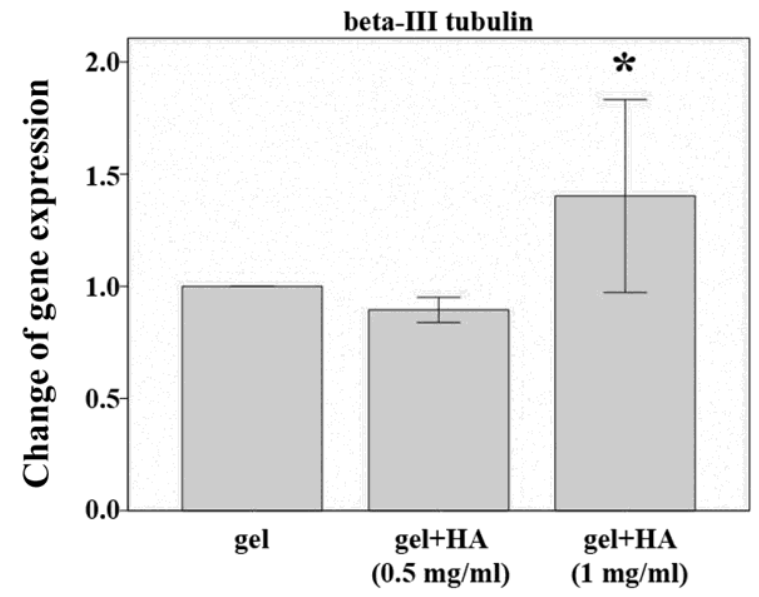

Figure 9 - Expression of beta-III tubulin gene: At 3 weeks, the expression of beta-III tubulin gene increased significantly on gelatin that contained 1 $\mathrm{mg} / \mathrm{ml}$ of HA.

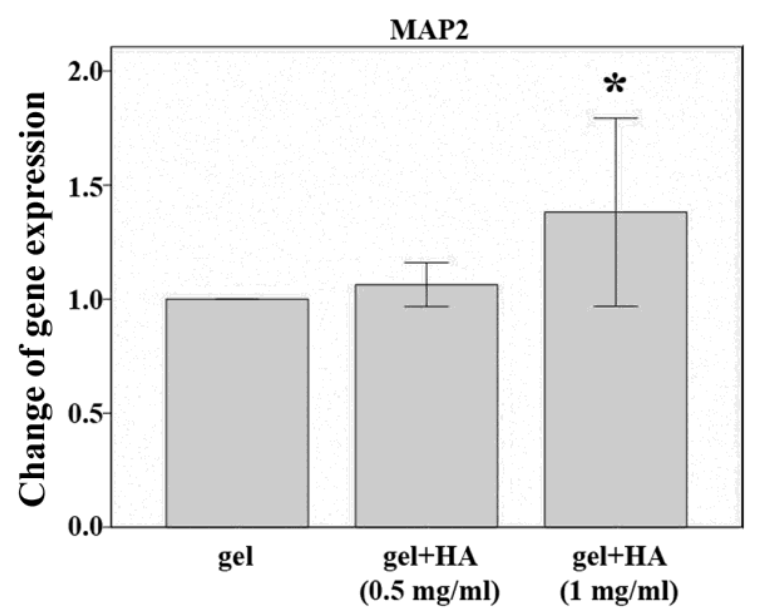

Figure 10 - Expression of MAP2 gene: At 3 weeks, the expression of MAP2 gene increased significantly on gelatin that contained $1 \mathrm{mg} / \mathrm{ml}$ of HA.

The expression of OPN on gelatin with 1 $\mathrm{mg} / \mathrm{ml}$ of HA was observed. It is well known that OPN is one of the bone differentiation markers. Misawa et al. reported that OPN was a selective marker of alpha motor neurons in the mouse spinal cord (Misawa et al., 2012). Additionally, up-regulation of nestin was equivalent in gelatin with 0.5 and $1 \mathrm{mg} / \mathrm{ml}$ of HA. A previous study by Wiese et al. suggested that nestin represented a characteristic marker of multi-lineage progenitor cells, suggesting that its presence in cells might indicate multi-potentiality and regenerative potential (Wiese et al., 2004). Recently, Ono et al. revealed that nestinexpressing cells were associated with vasculature and encompassed early cells in the osteoblast, stromal, and endothelial lineages (Ono et al., 2014). 
The previous study by Azami et al. combined $10 \mathrm{w} / \mathrm{v} \%$ gelatin and HA nanopowder to obtain a GEL(70)/HA(30) weight composition which presented excellent outcome for bone regeneration (Azami et al., 2010). Moreover this work also indicated that optimum concentration for crosslinking GEL matrix for bone regeneration is $1 \mathrm{w} / \mathrm{v} \%$ GA solution (Azami et al., 2010). However, the present study used much lower content of HA and GA which resulted in the different result of cell differentiation. The up-regulation of TUBB3 and MAP2 demonstrated the possibility of neuronal differentiation (Menezes and Luskin, 1994; Gambichler et al., 2009). The result pointed out that gelatin with $1 \mathrm{mg} / \mathrm{ml}$ of $\mathrm{HA}$ likely supported neuronal differentiation compared to pure gelatin and gelatin with 0.5 $\mathrm{mg} / \mathrm{ml}$ of HA. This study demonstrated that the addition of HA content into gelatin affected gene expression at 24 hours. The addition of HA did not seem to have much effect on expression of $\square$-actin. Small variations in HA content induced similar levels of nestin, gelsolin, and paxillin gene expression at 24 hours. However, in long-term culture, this small variation in HA amount affected cell differentiation, because HMSCs cultured on gelatin with $1 \mathrm{mg} / \mathrm{ml}$ of $\mathrm{HA}$ showed neuronal lineage differentiation. Previously, HA has been used for axonal guidance growth in cultured cortical neurons (Liu et al., 2012). More recently, Liu et al. indicated that nano-HA-coated magnetic nanoparticles increased cell viability and guided neuronal growth (Liu et al., 2015). The releasing of $\mathrm{Ca}^{2+}$ from Biphasic calcium phosphate bioceramics has been reported previously (Gallinetti et al., 2014; Seol et al., 2014). It has been hypothesized that the releasing of $\mathrm{Ca}^{2+}$ from the hydrogel activated the purinergic receptor of mesenchymal stem cells, which induced neuronal differentiation (Glaser et al., 2013).

\section{ACKNOWLEDGMENTS}

The authors acknowledge the main financial support received from the Research Administration Center, Chiang Mai University. Thanks for partial funding from the Faculty of Associated Medical Sciences, Chiang Mai University, Thailand. Finally the authors would like to give a special thank you to Prof. Kidoaki and Dr. Kuboki of Kyushu University for HMSCs.

\section{CONCLUSIONS}

The aim of this research was to inspect the change of gene expression using real timePCR, which reflects changes in HMSC behavior upon cultivation on gelatin with low HA content. Gelatin with $1 \mathrm{mg} / \mathrm{ml}$ of HA supported neuronal gene expression in HMSCs, compared with pure gelatin and gelatin with $0.5 \mathrm{mg} / \mathrm{ml}$ of HA. This result implies that gelatin composite HA needs to be delicately optimized before application. It can be concluded that small variations in HA content affected cell differentiation. HA enhancing cell adhesion on a soft substrate and, maybe together with the releasing of $\mathrm{Ca}^{2+}$, drive a cell response to change gene expression and differentiation.

\section{REFERENCES}

Azami M, Rabiee M, Moztarzadeh F. Glutaraldehyde crosslinked gelatin/hydroxyapatite nanocomposite scaffold, engineered via compound techniques. Polymer Composites. 2010;31(12):2112-20.

Azami M, Tavakol S, Samadikuchaksaraei A, Hashjin MS, Baheiraei N, Kamali M, et al. A Porous Hydroxyapatite/Gelatin Nanocomposite Scaffold for Bone Tissue Repair: In Vitro and In Vivo Evaluation. J Biomater Sci Polym Ed. 2012;23(18):2353-68.

Banat R, Tinçer T. Study on the properties of crosslinking of poly(ethylene oxide) and hydroxyapatite-poly(ethylene oxide) composite. Journal of Applied Polymer Science. 2003;90(2):488-96.

Chan CE, Odde DJ. Traction dynamics of filopodia on compliant substrates. Science. 2008;322(5908):1687-91.

Deligianni DD, Katsala ND, Koutsoukos PG, Missirlis YF. Effect of surface roughness of hydroxyapatite on human bone marrow cell adhesion, proliferation, differentiation and detachment strength. Biomaterials. 2001;22(1):87-96.

Discher DE, Janmey P, Wang YL. Tissue cells feel and respond to the stiffness of their substrate. Science. 2005;310(5751):1139-43.

Engler A, Bacakova L, Newman C, Hategan A, Griffin M, Discher D. Substrate compliance versus ligand density in cell on gel responses. Biophys J. 2004;86(1 Pt 1):617-28. 
Engler AJ, Sen S, Sweeney HL, Discher DE. Matrix elasticity directs stem cell lineage specification. Cell. 2006;126(4):677-89.

Gallinetti S, Canal C, Ginebra MP, Ferreira J. Development and Characterization of Biphasic Hydroxyapatite/ $\beta$-TCP Cements. J Am Ceram Soc. 2014;97(4):1065-73.

Gambichler T, Rotterdam S, Radkowski K, Altmeyer P, Kreuter A. Differential expression of microtubule-associated protein 2 in melanocytic skin lesions. Am J Clin Pathol. 2009;131(5):7104.

Glaser T, Resende RR, Ulrich H. Implications of purinergic receptor-mediated intracellular calcium transients in neural differentiation. Cell Commun Signal. 2013;11(1):12.

Gremm D, Wegner A. Gelsolin as a calciumregulated actin filament-capping protein. Eur $\mathrm{J}$ Biochem. 2000;267(14):4339-45.

Ji L, Chauhan A, Chauhan V. Calcium induces expression of cytoplasmic gelsolin in SH-SY5Y and HEK-293 cells. Neurochem Res. 2010;35(7):1075-82.

Kantawong F, Kuboki T, Kidoaki S. Redox gene expression of adipose-derived stem cells in response to soft hydrogel. Turk J Biol. 2015;39(5):682-91.

Kuboki T, Kantawong F, Burchmore R, Dalby MJ, Kidoaki S. 2D-DIGE Proteomic Analysis of Mesenchymal Stem Cell Cultured on the. Cell Struct Funct. 2012;37(2):127-39.

Laydi F, Rahouadj R, Cauchois G, Stoltz JF, de Isla $\mathrm{N}$. Hydroxyapatite incorporated into collagen gels for mesenchymal stem cell culture. Biomed Mater Eng. 2013;23(4):311-5.

Liu BS, Yang YC, Shen CC. Regenerative effect of adipose tissue-derived stem cells transplantation using nerve conduit therapy on sciatic nerve injury in rats. $\mathrm{J}$ Tissue Eng Regen Med. 2014;8(5):337-50.

Liu M, Zhou G, Hou Y, Kuang G, Jia Z, Li P, et al. Effect of nano-hydroxyapatite-coated magnetic nanoparticles on axonal guidance growth of rat dorsal root ganglion neurons. J Biomed Mater Res A. 2015;103(9):3066-71.

Liu M, Zhou G, Song W, Li P, Liu H, Niu X, et al. Effect of nano-hydroxyapatite on the axonal guidance growth of rat cortical neurons. Nanoscale. 2012;4(10):3201-7.

Martino NA, Reshkin SJ, Ciani E, Dell'Aquila ME. Calcium-sensing receptor-mediated osteogenic and early-stage neurogenic differentiation in umbilical cord matrix mesenchymal stem cells from a large animal model. PLoS One. 2014;9(11):e111533.

Menezes JR, Luskin MB. Expression of neuronspecific tubulin defines a novel population in the proliferative layers of the developing telencephalon. J Neurosci. 1994;14(9):5399-416.

Misawa H, Hara M, Tanabe S, Niikura M, Moriwaki Y, Okuda T. Osteopontin is an alpha motor neuron marker in the mouse spinal cord. J Neurosci Res. 2012;90(4):732-42.

Miyamoto S, Akiyama SK, Yamada KM. Synergistic roles for receptor occupancy and aggregation in integrin transmembrane function. Science. 1995;267(5199):883-5.

Munemoto S, Shibuya Y, Murata M, Takeuchi J, Ikehata N, Kobayashi M, et al. Effects of calcium phosphate cement on the peripheral nerve fibers. Kobe J Med Sci. 2010;55(4):E98-105.

Ono N, Ono W, Mizoguchi T, Nagasawa T, Frenette PS, Kronenberg HM. Vasculatureassociated cells expressing nestin in developing bones encompass early cells in the osteoblast and endothelial lineage. Dev Cell. 2014;29(3):330-9.

Selden LA, Kinosian HJ, Newman J, Lincoln B, Hurwitz C, Gershman LC, et al. Severing of Factin by the amino-terminal half of gelsolin suggests internal cooperativity in gelsolin. Biophys J. 1998;75(6):3092-100.

Seol YJ, Park JY, Jung JW, Jang J, Girdhari R, Kim SW, et al. Improvement of bone regeneration capability of ceramic scaffolds by accelerated release of their calcium ions. Tissue Eng Part A. 2014;20(21-22):2840-9.

Shen CC, Yang YC, Liu BS. Peripheral nerve repair of transplanted undifferentiated adipose tissue-derived stem cells in a biodegradable reinforced nerve conduit. J Biomed Mater Res A. 2012;100(1):48-63.

Solon J, Levental I, Sengupta K, Georges PC, Janmey PA. Fibroblast adaptation and stiffness matching to soft elastic substrates. Biophys J. 2007;93(12):4453-61.

Southwick FS. Gelsolin and ADF/cofilin enhance the actin dynamics of motile cells. Proc Natl Acad Sci U S A. 2000;97(13):6936-8.

Suzuki S, Namiki J, Shibata S, Mastuzaki Y, Okano H. The neural stem/progenitor cell marker nestin is expressed in proliferative endothelial cells, but not in mature vasculature. J Histochem Cytochem. 2010;58(8):721-30.

Tanum J, Udomsom S, Wattanutchariya W, Sooksaen P, Kantawong F. Characterization of gelatin composite with low content hydroxyapatite. KEM. 2016;675-676:473-6.

Tavakol S, Azami M, Khoshzaban A, Ragerdi Kashani I, Tavakol B, Hoveizi E, et al. Effect of laminated hydroxyapatite/gelatin nanocomposite scaffold structure on osteogenesis using unrestricted somatic stem cells in rat. Cell Biol Int. 2013;37(11):1181-9.

Turner CE. Paxillin interactions. J Cell Sci. 2000;113 Pt 23:4139-40.

Turner CE, Glenney JR, Burridge K. Paxillin: a new vinculin-binding protein present in focal adhesions. J Cell Biol. 1990;111(3):1059-68.

Walcott S, Kim DH, Wirtz D, Sun SX. Nucleation and decay initiation are the stiffness-sensitive phases of focal adhesion maturation. Biophys $\mathbf{J}$. 2011;101(12):2919-28. 
Variation of Hydroxyapatite Content in Soft Gelatin Affects Mesenchymal Stem Cell Differentiation

Wiese C, Rolletschek A, Kania G, Blyszczuk P,

Received: 25 October 2015

Tarasov KV, Tarasova $\mathrm{Y}$, et al. Nestin expression--a property of multi-lineage Accepted: 07 March 2016 progenitor cells? Cell Mol Life Sci. 2004;61(1920):2510-22.

Yeung T, Georges PC, Flanagan LA, Marg B, Ortiz M, Funaki M, et al. Effects of substrate stiffness on cell morphology, cytoskeletal structure, and adhesion. Cell Motil Cytoskeleton. 2005;60(1):24-34. 